\title{
Cerebral embolic protection devices during transcatheter aortic valve implantation: clinical versus silent embolism
}

\author{
Luis Nombela-Franco, German Armijo, Gabriela Tirado-Conte \\ Cardiovascular Institute, Hospital Clínico San Carlos, IdISSC, Madrid, Spain \\ Contributions: (I) Conception and design: L Nombela-Franco; (II) Administrative support: None; (III) Provision of study materials or patients: \\ None; (IV) Collection and assembly of data: None; (V) Data analysis and interpretation: L Nombela-Franco; (VI) Manuscript writing: All authors; \\ (VII) Final approval of manuscript: All authors. \\ Correspondence to: Luis Nombela-Franco, MD, PhD. Cardiovascular Institute, Hospital Universitario Clínico San Carlos, IdISSC, 28040 Madrid, \\ Spain. Email: luisnombela@yahoo.com.
}

\begin{abstract}
Cerebrovascular events following transcatheter aortic valve implantation (TAVI) is one of the most devastating complications. Several studies with magnetic resonance or cerebral filters have demonstrated the universal brain embolization after TAVI, in the majority of patients clinically silent. Embolic protection devices (EPD) have been developed as a mechanical barrier to prevent these emboli to reach cerebral vasculature and potentially reduce neurological events. We review the current evidence about EPD in relation to histopathological and cerebral imaging findings and neurological events.
\end{abstract}

Keywords: Transcatheter aortic valve implantation (TAVI); transcatheter aortic valve replacement (TAVR); stroke, cerebrovascular events; embolic protection device (EPD)

Submitted Sep 03, 2018. Accepted for publication Sep 14, 2018.

doi: $10.21037 /$ jtd.2018.09.62

View this article at: http://dx.doi.org/10.21037/jtd.2018.09.62

\section{Introduction}

Transcatheter aortic valve implantation (TAVI) is an established therapy for inoperable, high and moderate-risk patients with symptomatic aortic stenosis (1). Therefore, as TAVI has become an important option for an increasing number of patients, its complications should be minimized as much as possible. Cerebrovascular events (CVE) are one of the most feared complications following TAVI due to the enormous impact on patient's quality of life, morbidity and mortality (2-5). In fact, in the first placement of aortic transcatheter valve (PARTNER) randomized clinical trial (RCT) some concerns reached since the incidence of CVE was significantly higher in patients receiving TAVI compare with those undergoing surgical replacement ( $5.5 \%$ vs. $2.4 \%$ stroke incidence at 30 days, $\mathrm{P}=0.04$ ) (6). Fortunately, current data showed lower rate of neurological complications with no difference compared to surgery $(7,8)$. Nevertheless, prevention strategies to decrease CVE rate are critical prior to expand TAVI indication to younger, lower risk patients. Several imaging and histopathological studies have demonstrated that the majority of CVE after TAVI have an embolic origin, from debris embolization or thrombus formation (9). Embolic protection devices (EPD) have emerged as a mechanical protection strategy to prevent these emboli to reach the cerebral vasculature and decrease the associated neurological effects. The objective of this article is to provide an overview of the current knowledge of EPD.

\section{Characteristics of EPD}

To date, five different types of EPD, in the form of filters or deflectors have been tested and reported during TAVI procedures (Figure 1). Main characteristics in terms of design, cerebral protected territories and access routes are summarized in Table 1. While, filter devices have the advantage to obtain the embolized material, deflector-type systems are released in the aortic arch rejecting the debris towards the descending aorta, with a theoretically higher probability of peripheral embolism. 

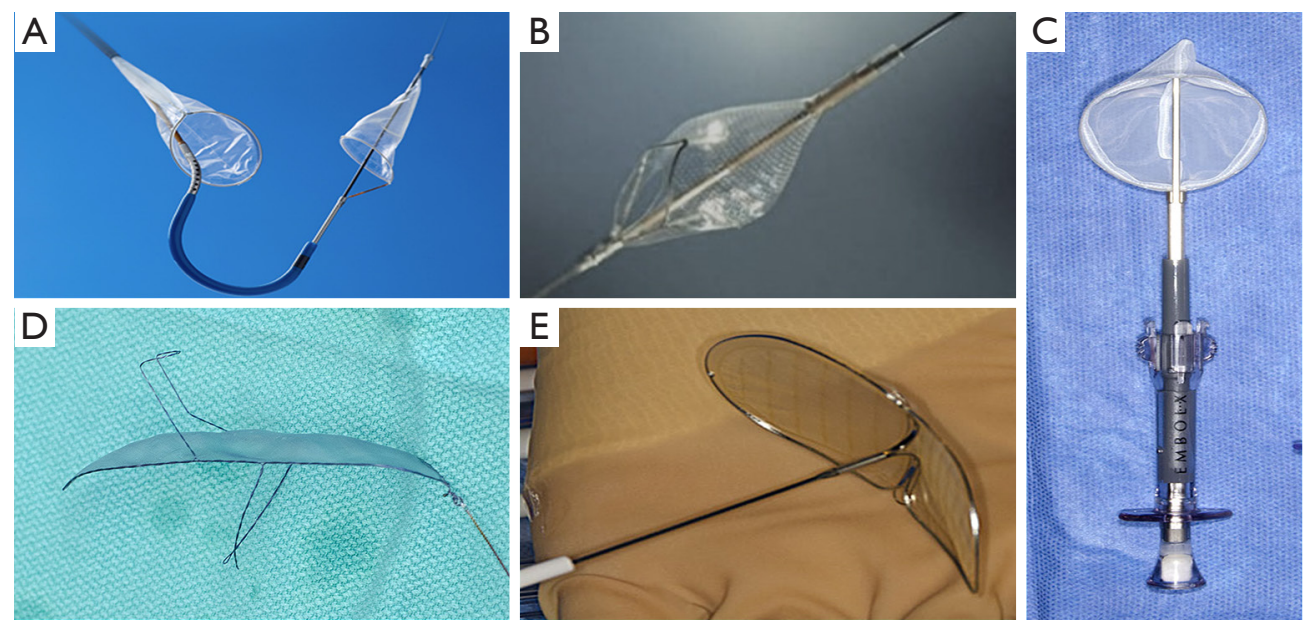

Figure 1 Types of cerebral protection devices. (A) Sentinel (Boston Scientific Corp.); (B) Wirion (Allium Medical Inc.); (C) Embol-X (Edwards Lifesciences); (D) TriGuard (Keystone Heart Ltd); (E) Embrella (Edwards Lifesciences).

Table 1 Main characteristics of the embolic protection devices

\begin{tabular}{|c|c|c|c|c|c|c|c|}
\hline Design & Device & Manufacturer & Access & $\begin{array}{l}\text { Delivery } \\
\text { system }\end{array}$ & Deployment & $\begin{array}{l}\text { Protected } \\
\text { cerebral territories }\end{array}$ & $\begin{array}{l}\text { Pore size } \\
(\mu \mathrm{m})\end{array}$ \\
\hline \multirow[t]{2}{*}{ Deflector } & Embrella & $\begin{array}{l}\text { Edwards Lifesciences, } \\
\text { Irvine, CA }\end{array}$ & $\begin{array}{l}\text { Radial or } \\
\text { brachial artery }\end{array}$ & $6 \mathrm{~F}$ & Aortic arch & Partial protection & 100 \\
\hline & TriGuard & $\begin{array}{l}\text { Keystone Heart Ltd, } \\
\text { Caesarea, Israel }\end{array}$ & Femoral artery & $9 \mathrm{~F}$ & Aortic arch & Full protection & 140 \\
\hline \multirow{2}{*}{ Filter } & Claret Sentinel & $\begin{array}{l}\text { Boston } \\
\text { Scientific Corp. }\end{array}$ & $\begin{array}{l}\text { Radial or } \\
\text { brachial artery }\end{array}$ & $6 \mathrm{~F}$ & $\begin{array}{l}1 \text { filter to brachiocephalic } \\
\text { trunk and } 1 \text { filter to left } \\
\text { common carotid }\end{array}$ & Partial protection* & 140 \\
\hline & Wirion & $\begin{array}{l}\text { Allium Medical, Inc., } \\
\text { Caesarea, Israel }\end{array}$ & $\begin{array}{l}\text { Radial or } \\
\text { brachial artery }\end{array}$ & $6 \mathrm{~F}$ & $\begin{array}{l}1 \text { filter in any vessel of } 3.5 \\
\text { to } 6 \mathrm{~mm} \text { diameter }\end{array}$ & Partial protection* & 120 \\
\hline
\end{tabular}

*, Full protection in combination with the Wirion filter in the left vertebral artery.

The Sentinel device (Boston Scientific, Corp.) is a dual system filter, released in the brachiocephalic trunk and the left common carotid advanced in a 6-Fr sheath from the right upper extremity (Figure 1A). Using an articulating sheath, the curve of the device can be adjusted to accommodate anatomic variations of the aortic arch. It has received FDA approval in 2017 and it is to date the most widely used EPD in TAVI (it is the only device available in US). One limitation was the incomplete cerebral coverage, which may be solved, in combination with the Wirion Filter (Allium Medical, Inc.) placed in the left vertebral artery for full cerebral coverage (10) (Figure 1B). The Embol-X (Edwards Lifesciences, $\mathrm{CA}$ ) is another filter system that was initially designed to use during conventional cardiac surgery and requires direct access to the ascending aorta (Figure 1C). A modified version has been tested in transaortic TAVI with full cerebral coverage. The Triguard device (Keystone Heart, Ltd) is a deflector device placed through a femoral 9-Fr sheath with a parallel use of a pigtail (Figure 1D). It provides full cerebral protection covering the 3 branches of the aortic arch with a semi-permeable mesh that deflects particles larger than $140 \mu \mathrm{m}$. Finally, the Embrella deflector device (Edwards Lifesciences, CA) (Figure 1E), which is no longer under development, but was the earliest dedicated device for TAVI (11). It is used via the right radial (or brachial) artery with a 6-Fr sheath and advance into the 


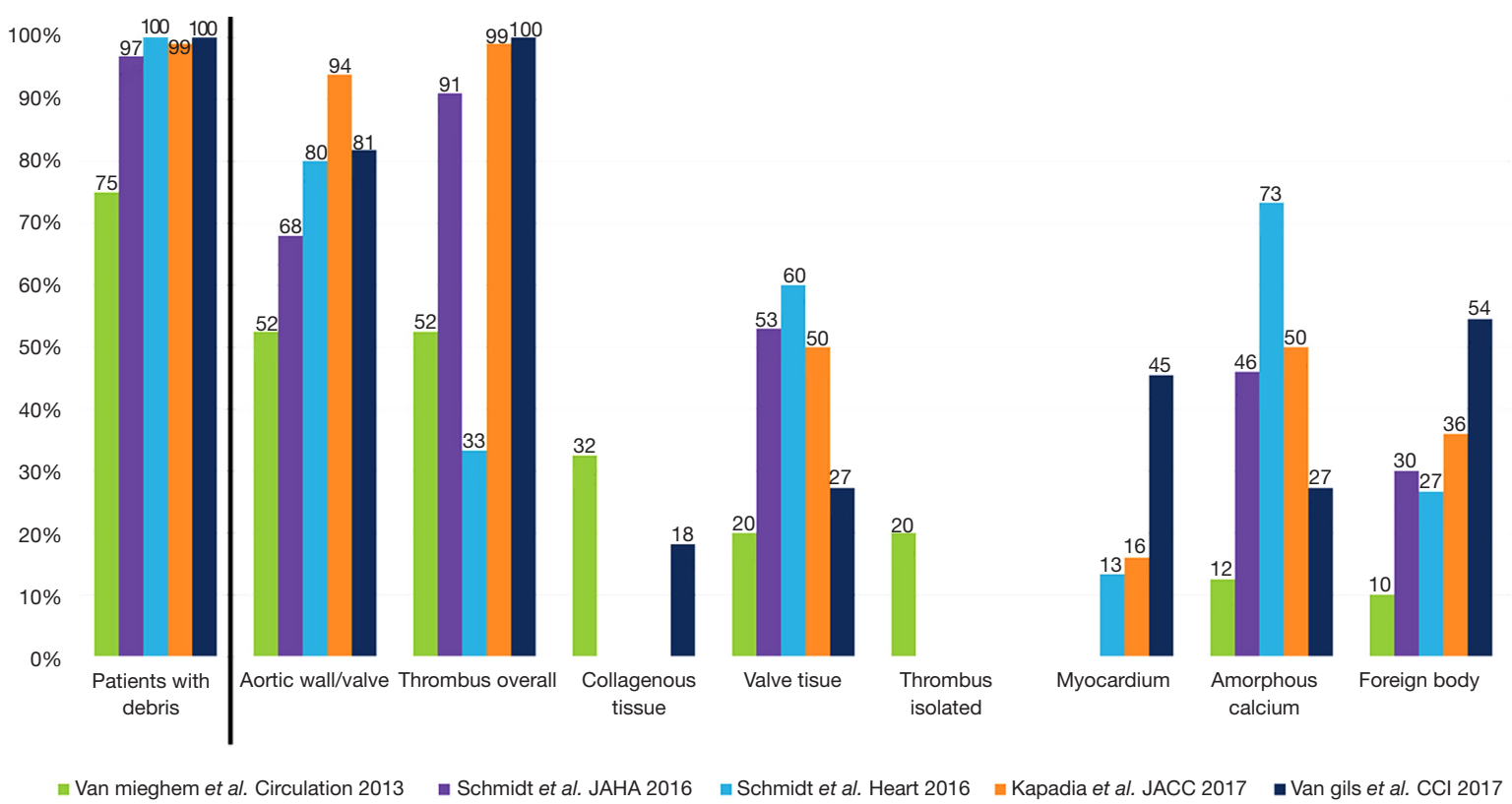

Figure 2 Frequency and distribution of captured debris in histopathologic analysis. Adapted from Armijo et al. (9).

aortic arch where the device covered brachiocephalic trunk and left common carotid, leaving left vertebral artery unprotected in most of the cases.

\section{Subclinical data}

Filter EPD helped extensively to understand the frequency and nature of the embolized material during the TAVI procedure. Initially, cerebral magnetic resonance imaging (MRI) studies demonstrated that new cerebral lesions, mostly silent, were observed in a high percentage of patients undergoing TAVI (ranging from 60\% to 90\%) (12-14). These lesions were not associated to the access route or the valve type, and were frequently diffuse and multiple, from anterior and posterior cerebral vascular territories, suggesting an embolic nature. Later, the embolic origin of these lesions was further reinforced by transcranial Doppler studies that quantified high intensity transient signals in the middle cerebral artery during TAVI. While these signals were observed over all phases of the procedure, the greatest number of signals occurred during valve positioning for self-expandable valves and valve implantation during balloon inflation $(15,16)$. Finally, studies using cerebral filters wisely demonstrated that the majority of the patients undergoing TAVI had debris retained in the filter. Initially Van Mieghen et al. showed that the emboli were $\sim 1 \mathrm{~mm}$ size being the majority of fibrin or thrombotic nature (17). Posteriorly, other studies corroborated these findings $(10,18-21)$. The frequency and nature in histopathologic analysis of the debris in different studies are depicted in Figure 2.

\section{Clinical data}

EPD data in TAVI procedure is based on several observational studies (10,11,22-29) and five randomized clinical trials (20,30-33). Most of them had a very low sample size and were non-powered to detect clinical outcomes. With the intention to detect differences in mortality or neurological events, several meta-analysis combined the results of these studies. Main characteristics and results of observational and randomized studies are summarized in Table 2.

\section{Randomized trials}

The EMBOL-X trial, which was prematurely interrupted with 30 patients included (only 14 with the filter), had a no effect in the frequency of new brain lesions $(57 \% v s$. $69 \%, \mathrm{P}=0.70)$ and volume lesions $\left(88 \pm 60 v s .168 \pm 217 \mathrm{~mm}^{3}\right.$, $\mathrm{P}=0.27)$ in the MRI performed within 7 days postprocedure (30). However, the filter group had significantly smaller lesion volumes in the supply area of the middle cerebral artery $\left(33 \pm 29 v s .76 \pm 67 \mathrm{~mm}^{3}, \mathrm{P}=0.04\right)$.

The DEFLECT III multicenter randomized trial with 
Table 2 Main characteristics of non-randomized and randomized studies with embolic protection devices

\begin{tabular}{|c|c|c|c|c|c|c|}
\hline Study & Year & Device & $\begin{array}{l}\text { Total } n \text { of } \\
\text { patients } / n \text { of } \\
\text { patients with } \\
\text { EPD }\end{array}$ & Design & $\begin{array}{l}\text { Objectives/primary } \\
\text { outcome }\end{array}$ & Main results \\
\hline \multicolumn{7}{|l|}{ Observational } \\
\hline $\begin{array}{l}\text { Nietlispach } \\
\text { et al. (11) }\end{array}$ & 2010 & Embrella & $4 / 4$ & Case series & $\begin{array}{l}\text { Describe initial human } \\
\text { experience }\end{array}$ & $\begin{array}{l}\text { Correct placement in all the patients } \\
\text { Additional procedure time: } \\
13 \text { minutes } \\
\text { A } 5 \mathrm{~mm} \text { acute subclinical cortical } \\
\text { infarct in one patient }\end{array}$ \\
\hline $\begin{array}{l}\text { Naber } \\
\text { et al. (22) }\end{array}$ & 2012 & $\begin{array}{l}\text { Claret CE Pro } \\
+ \text { SpiderFX } \\
\text { carotid filter }\end{array}$ & $40 / 40$ & $\begin{array}{l}\text { Case series, } \\
\text { prospective, } \\
3 \text { centers }\end{array}$ & $\begin{array}{l}\text { Describe initial human } \\
\text { experience } \\
\text { Technical success rate }\end{array}$ & $\begin{array}{l}\text { Technical success rate: } 87.5 \% \\
\text { Captured debris: } 54 \% \\
2 \text { major strokes and } 1 \text { minor stroke } \\
\text { (30-day) }\end{array}$ \\
\hline $\begin{array}{l}\text { Onsea } \\
\text { et al. (23) }\end{array}$ & 2012 & $\begin{array}{l}\text { SMT embolic } \\
\text { deflector }\end{array}$ & $15 / 15$ & Case series & $\begin{array}{l}\text { Describe first in man } \\
\text { experience }\end{array}$ & $\begin{array}{l}\text { Successful placement: } 100 \% \\
\text { Additional procedure time: } 7 \text { minutes } \\
\text { New cerebral lesions: } 3.2 \text { per patient } \\
\text { ( } 7.2 \text { in an historical cohort) } \\
1 \text { transient ischemic attack }\end{array}$ \\
\hline $\begin{array}{l}\text { Rodés-Cabau } \\
\text { et al. Pro-TAVI } \\
\text { C (24) }\end{array}$ & 2014 & Embrella & $52 / 41$ & $\begin{array}{l}\text { Prospective, } \\
\text { non-randomized, } \\
\text { comparative } \\
\text { study }\end{array}$ & $\begin{array}{l}\text { Feasibility, safety and } \\
\text { exploratory efficacy } \\
\text { Control group with HITS } \\
\text { and MRI studies }\end{array}$ & $\begin{array}{l}\text { Correct placement in all the patients } \\
\text { More HITS in the device group } \\
\text { All patients had new lesions (day } \leq 7 \text { ) } \\
\text { and disappeared at } 30 \text {-day. Same } \\
\text { number of patients with multiple } \\
\text { lesions in both groups } \\
\text { Device associated with lower lesion } \\
\text { volume }\end{array}$ \\
\hline $\begin{array}{l}\text { Samin } \\
\text { et al. (25) }\end{array}$ & 2015 & Embrella & $52 / 15$ & $\begin{array}{l}\text { Prospective, } \\
\text { non-randomized, } \\
\text { multi-centre, } \\
\text { single-arm study }\end{array}$ & $\begin{array}{l}\text { Compare cerebral injury } \\
\text { with and without EPD } \\
\text { MRI at day } 4 \text { after TAVI }\end{array}$ & $\begin{array}{l}\text { Patients with new brain lesions } \\
(100 \% \text { vs. } 95 \%) \\
\text { Increase in number of new ischemic } \\
\text { lesions ( } 9 \text { vs. } 5, P=0.044) \text { in the EPD } \\
\text { group } \\
\text { Reduction in single lesion volume } \\
\text { (9.7 vs. } 17.8 \mu \mathrm{L}, \mathrm{P}<0.001)\end{array}$ \\
\hline $\begin{array}{l}\text { Van Mieghem } \\
\text { et al. (26) }\end{array}$ & 2015 & $\begin{array}{l}\text { Montage Dual } \\
\text { Filter }\end{array}$ & $81 / 81$ & Case series & $\begin{array}{l}\text { Histopathological analysis } \\
\text { of tissue embolization }\end{array}$ & $\begin{array}{l}\text { Debris captured in } 86 \% \text { of patients } \\
\text { Thrombotic material }(74 \%) \text { and tissue } \\
\text { debris }(63 \%) \\
\text { Tissue material more often with } \\
\text { balloon expandable valve and more } \\
\text { oversizing }\end{array}$ \\
\hline
\end{tabular}

Table 2 (continued) 
Table 2 (continued)

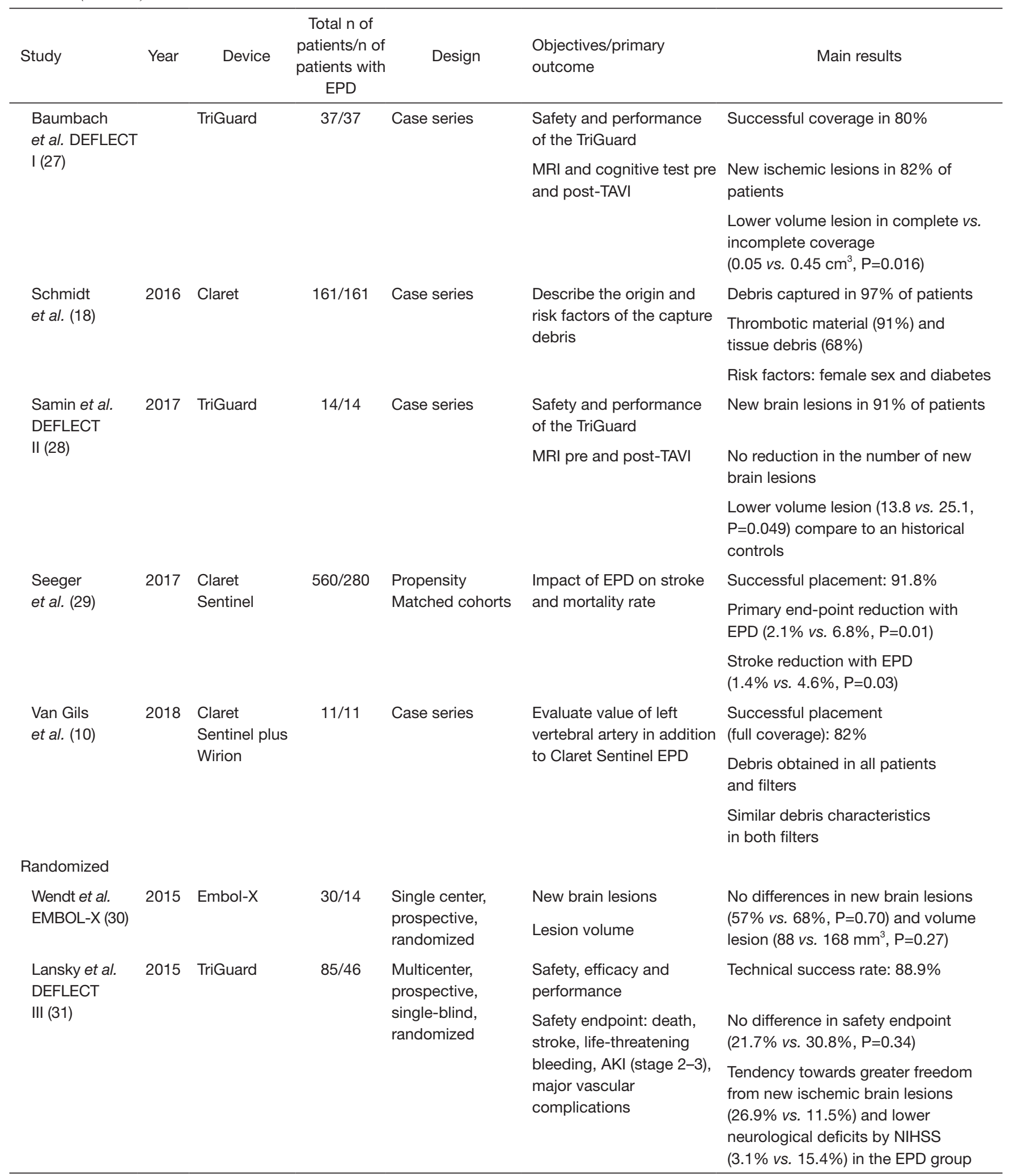

Table 2 (continued) 
Table 2 (continued)

\begin{tabular}{|c|c|c|c|c|c|c|}
\hline Study & Year & Device & $\begin{array}{l}\text { Total } n \text { of } \\
\text { patients } / \mathrm{n} \text { of } \\
\text { patients with } \\
\text { EPD }\end{array}$ & Design & $\begin{array}{l}\text { Objectives/primary } \\
\text { outcome }\end{array}$ & Main results \\
\hline \multirow{3}{*}{$\begin{array}{l}\text { Van Mieghem } \\
\text { et al. } \\
\text { MISTRAL-C } \\
\text { (32) }\end{array}$} & \multirow[t]{3}{*}{2016} & \multirow[t]{3}{*}{$\begin{array}{l}\text { Claret } \\
\text { Sentinel }\end{array}$} & \multirow[t]{3}{*}{$65 / 32$} & \multirow{3}{*}{$\begin{array}{l}\text { Multicenter, } \\
\text { prospective, } \\
\text { double blind, } \\
\text { randomized }\end{array}$} & \multirow{3}{*}{$\begin{array}{l}\text { Evaluate the utility of } \\
\text { EPD in new brain lesion } \\
\text { and neurocognitive } \\
\text { performance }\end{array}$} & $\begin{array}{l}\text { EPD success }(94 \%) \\
\text { material capture }(100 \%)\end{array}$ \\
\hline & & & & & & $\begin{array}{l}\text { No differences in } \% \text { of patients with } \\
\text { new cerebral lesion and number of } \\
\text { lesions }\end{array}$ \\
\hline & & & & & & $\begin{array}{l}\text { Smaller total lesion volume (95 vs. } \\
197 \mathrm{~mm}^{3}, \mathrm{P}=0.17 \text { ) and less patients } \\
\text { with multiple new lesions ( } 0 \text { vs. } 20 \% \text { ) }\end{array}$ \\
\hline \multirow{2}{*}{$\begin{array}{l}\text { Haussig et al. } \\
\text { CLEAN-TAVI } \\
\text { (33) }\end{array}$} & \multirow[t]{2}{*}{2016} & \multirow[t]{2}{*}{$\begin{array}{l}\text { Claret } \\
\text { Montage }\end{array}$} & \multirow[t]{2}{*}{$50 / 50$} & \multirow{2}{*}{$\begin{array}{l}\text { Single center, } \\
\text { prospective, } \\
\text { randomized }\end{array}$} & \multirow{2}{*}{$\begin{array}{l}\text { Effect of EPD on the } \\
\text { number and volume of } \\
\text { cerebral lesions after TAVI }\end{array}$} & $\begin{array}{l}\text { Lower number of new lesions in the } \\
\text { EPD group ( } 4 \text { vs. } 10, P=0.001)\end{array}$ \\
\hline & & & & & & No difference in clinical events \\
\hline \multirow[t]{3}{*}{$\begin{array}{l}\text { Kapadia et al. } \\
\text { SENTINEL (20) }\end{array}$} & \multirow[t]{3}{*}{2017} & \multirow[t]{3}{*}{$\begin{array}{l}\text { Claret } \\
\text { Sentinel }\end{array}$} & \multirow[t]{3}{*}{$363 / 244$} & \multirow{3}{*}{$\begin{array}{l}\text { Multicenter, } \\
\text { prospective, } \\
\text { randomized }\end{array}$} & \multirow{3}{*}{$\begin{array}{l}\text { Safety and clinical efficacy } \\
\text { (MACCE) of EPD during } \\
\text { TAVI }\end{array}$} & $\begin{array}{l}\text { EPD success }(100 \%) \text {; material } \\
\text { capture }(99 \%)\end{array}$ \\
\hline & & & & & & $\begin{array}{l}\text { No difference in MACCE } \\
\text { ( } 7.3 \text { vs. } 9.9 \%, P=0.41) \text {, volume of } \\
\text { new lesion }\left(103 \text { vs. } 178 \mathrm{~mm}^{3}, P=0.33\right)\end{array}$ \\
\hline & & & & & & $\begin{array}{l}\text { Early stroke was reduced in the EPD } \\
\text { group }(3.0 \% \text { vs. } 8.2 \%, P=0.05)\end{array}$ \\
\hline
\end{tabular}

AKI, acute kidney injury; MRI, magnetic resonance imaging; HITS, high-intensity transient signal; MACCE, major adverse cardiac and cerebrovascular events.

85 patients enrolled, evaluated the TriGuard system in terms of clinical and neurocognitive outcomes and MRI findings at baseline, discharge and 1 month follow-up (31). The device was successfully placed to cover full cerebral vasculature in $89 \%$ of cases. The primary in-hospital safety endpoint (a composite of death, stroke, major bleeding or major vascular complication and stage 2 or 3 acute kidney injury) occurred in $21.7 \%$ of the device group compared to $30.8 \%$ in the control group $(\mathrm{P}=0.34)$. In patients with complete cerebral coverage, TriGuard was associated with higher rate of freedom from new brain lesions at 1-month (26.9\% vs. $11.5 \%$, p not reported) and lower neurological deficit in NIHSS scale $(3.1 \%$ vs. $15.4 \%, \mathrm{P}=0.16)$. The REFLECT trial (NCT02536196) with larger sample size will further test the efficacy of the TriGuard device.

There were three randomized trial with the Sentinel system, accumulating the major evidence to date with this device. The first trial was the MISTRAL-C conducted in four centers in the Netherlands and randomized 65 patients into 1:1 TAVI with or without the device (32). The filter obtained material in all the patients in the intervention group. However, the primary endpoint (percentage of patients with new brain lesions in each group) was not reduced in the device group $(73 \%$ vs. $87 \%, \mathrm{P}=0.31)$ with a tendency to lower volume lesion (95 vs. $197 \mathrm{~mm}^{3}, \mathrm{P}=0.171$ ). Multiple brain lesions $(\geq 10)$ were only observed in the group without the device $(0 \%$ vs. $20 \%, \mathrm{P}=0.03)$ as well as higher cognitive impairment (4\% vs. $27 \%, \mathrm{P}=0.017$ ). Major limitation of the study was that MRI images and neurocognitive test were only obtained in $57 \%$ and $80 \%$ of patients, respectively. The second trial was the CLEAN-TAVI that randomized one hundred patients (1:1) in a single center in Germany to perform TAVI with or without the Claret Sentinel device (33). The number of new post-procedure cerebral lesions was significantly lower in the protected brain areas compared to the control group 
(4 vs. $10, \mathrm{P}=0.001$ ) at 2 days after the intervention. Also, new lesion volume was lower in the filter group compared to the control group (242 vs. $527 \mathrm{~mm}^{3}$ ) (difference $234 \mathrm{~mm}^{3}$, 95\% CI: 91-406; $\mathrm{P}=0.001)$. There was not difference in the number of CVE ( 5 minor strokes in each group). Finally the landmark study with EPD was the SENTINEL multicenter, prospective and randomized trial, which included 363 TAVI patients from 19 centers in US and Germany (20). Patients were distributed in 1:1:1 into a safety arm with the device and two imaging arms that randomly underwent TAVI with and without the device. Neurocognitive assessment and neurologist evaluation was rigorously scheduled before, at 30- and 90-day follow-up with an independent adjudicated clinical events committee. The primary safety endpoint included major adverse cardiac and CVE (MACCE) at 30-day with the primary efficacy endpoint of reduction in new lesion volume in protected cerebral territories on MRI performed at 2-7 days post-TAVI. The device was successfully implanted in all the patients, and debris were obtained in $99 \%$ of the patients. MACCE was non-inferior in the device group $(7.3 \%$ vs. $9.9 \%, \mathrm{P}=0.41)$. Volume of new cerebral lesions was also similar in both groups (102.8 vs. $\left.178.0 \mathrm{~mm}^{3}, \mathrm{P}=0.33\right)$. The stroke rate was numerically lower in the device group $(5.6 \%$ vs. $9.1 \%, \mathrm{P}=0.25)$. In a post-hoc analysis, periprocedural ( $\leq 72$ hours) stroke rate was reduced in the device group $(3.0 \%$ vs. $8.2 \%, \mathrm{P}=0.05)$. Although there was a correlation between lesion volume and neurocognitive impairment, the device did not demonstrate any benefit in neurocognitive function. The authors concluded that Sentinel device could be safely used and captured material in almost all the patients leading to a non-significant reduction in new lesion volume in MRI studies and no change in neurocognitive function.

It is worth mentioning a recent single-center, non-randomized study that included 280 patients treated with the Sentinel device and compared to an historical cohort of 522 patients without the device (29). After a propensity score matching ( $\mathrm{n}=280$ in each group), the primary end-point (a composite of mortality or stroke within 7 days) was significantly reduced in the protected group $(2.1 \%$ vs. $6.8 \%, \mathrm{P}=0.01)$. Also in multivariate analysis, TAVI without the device was an independent predictor for the primary end-point.

\section{Meta-analysis}

Several meta-analyses have combined the results of the randomized controlled trials and some comparative observational studies (33-40). Main characteristics and findings of published meta-analysis are summarized in Table 3. The principal limitations of the meta-analysis were the small number of trials, patients and clinical events, and the high rate of loss to follow-up in most of studies. All meta-analysis concluded that EPD did not reduce the number of new ischemic lesions or the number of patients with new ischemic lesions. However, total lesion volume and single lesion volume was significantly reduced by EPD. Results regarding clinical outcomes such as stroke or mortality were more controversial (41). Some studies reported a non-significant tendency in 30-day stroke or mortality rate $(34,36,38)$, while others observed a significant reduction in the combined endpoint of 7- (38) or 30 -day $(39,40)$ stroke or mortality rate. Differences in the inclusion and exclusion criteria, time for event evaluation, and different analytic method used for the analysis (fixed versus random effect analysis) may explain these disparities among the studies. Lastly, there are not head-to-head studies between different EPD, which allow comparing filter or deflector devices. Patient-level data analysis would likely be more appropriate to provide more accurate conclusions and the true effectiveness of these devices for stroke prevention in patients undergoing TAVI.

\section{Conclusions}

There is no doubt about the clinical importance of CVE in patient's quality of life and mortality. Therefore the goal is to reduce CVE rate following TAVI. The procedure per se is associated with different nature of material embolization and previous reports with MRI, transcranial Doppler and histopathology studies have clearly demonstrated cerebral embolization during the procedure in the majority of the patients. Potential clinical late implications and cognitive decline of these universally "silent" cerebral lesions need to be well defined in the future, especially for younger patients undergoing TAVI. EPD have emerged as mechanical treatment to prevent cerebral embolization. The current research design of EPD focuses on the silent cerebral lesion in MRI studies as a surrogate marker of the clinical disease. While EPD had a reduction in volume of these cerebral lesions, the number of patients with new cerebral lesions or the total number of lesions has not been consistently reduced by EPD across different studies. The beneficial effect of EPD in patients undergoing TAVI is currently based on observational studies or post-hoc analysis of randomized trials. In addition, the advantage of universally 
Table 3 Published meta-analysis with embolic protection device during transcatheter aortic valve replacement

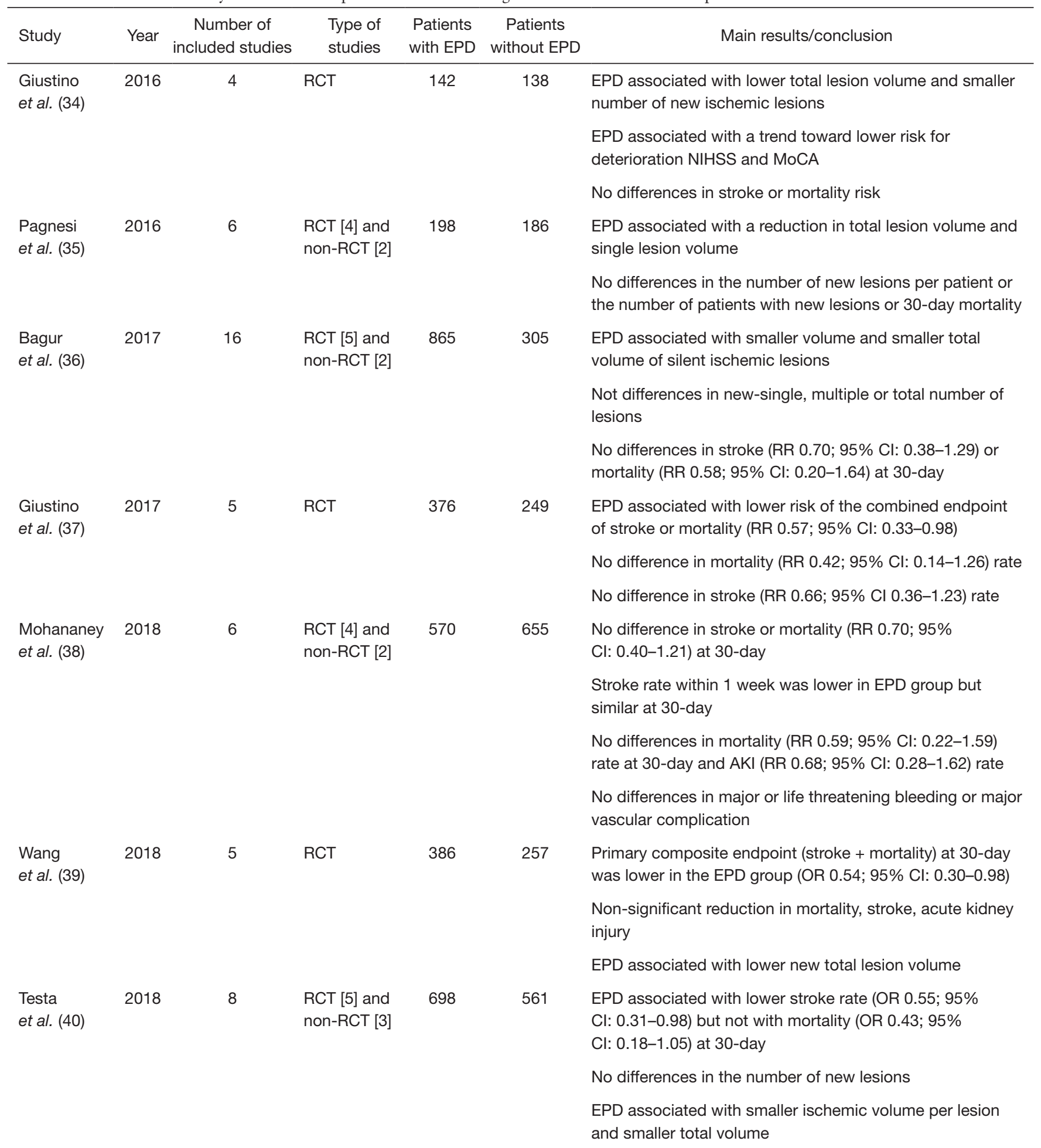

EPD, embolic protection device; MoCA, Montreal Cognitive Assessment; NIHSS, National Institutes of Health Stroke Scale; RCT, randomized controlled trial. 
versus selected used of EDP in terms of reduction in hard clinical events remains to be defined. Thus, future analysis and adequately powered and randomized studies will have to further clarify the efficacy of EPD in TAVI. The multifactorial nature of CVE following TAVI make the goal of reducing CVE, a multifaceted process with several preventive strategies, not only during the procedure with EPD, but also in the pre- and post-procedural phases with proper antithrombotic regimens and monitoring for other risk factors.

\section{Acknowledgements}

None.

\section{Footnote}

Conflicts of Interest: The authors have no conflicts of interest to declare.

\section{References}

1. Baumgartner H, Falk V, Bax JJ, et al. 2017 ESC/EACTS Guidelines for the management of valvular heart disease. Eur Heart J 2017;38:2739-91.

2. Nombela-Franco L, Webb JG, de Jaegere PP, et al. Timing, predictive factors, and prognostic value of cerebrovascular events in a large cohort of patients undergoing transcatheter aortic valve implantation. Circulation 2012;126:3041-53.

3. Muralidharan A, Thiagarajan K, Van Ham R, et al. Meta-analysis of perioperative stroke and mortality in transcatheter aortic valve implantation. Am J Cardiol 2016;118:1031-45.

4. Gleason TG, Schindler JT, Adams DH, et al. The risk and extent of neurologic events are equivalent for high-risk patients treated with transcatheter or surgical aortic valve replacement. J Thorac Cardiovasc Surg 2016;152:85-96.

5. Kapadia S, Agarwal S, Miller DC, et al. Insights Into Timing, Risk Factors, and Outcomes of Stroke and Transient Ischemic Attack After Transcatheter Aortic Valve Replacement in the PARTNER Trial (Placement of Aortic Transcatheter Valves). Circ Cardiovasc Interv 2016;9.

6. Smith CR, Leon MB, Mack MJ, et al. Transcatheter versus surgical aortic-valve replacement in high-risk patients. $\mathrm{N}$ Engl J Med 2011;364:2187-98.

7. Adams DH, Popma JJ, Reardon MJ, et al. Transcatheter aortic-valve replacement with a self-expanding prosthesis. N Engl J Med 2014;370:1790-8.
8. Thourani VH, Kodali S, Makkar RR, et al. Transcatheter aortic valve replacement versus surgical valve replacement in intermediate-risk patients: a propensity score analysis. Lancet 2016;387:2218-25.

9. Armijo G, Nombela-Franco L, Tirado-Conte G. Cerebrovascular events after transcatheter aortic valve implantation. Front Cardiovasc Med 2018;5:104.

10. Van Gils L, Kroon H, Daemen J, et al. Complete filter-based cerebral embolic protection with transcatheter aortic valve replacement. Catheter Cardiovasc Interv 2018;91:790-7.

11. Nietlispach F, Wijesinghe N, Gurvitch R, et al. An embolic deflection device for aortic valve interventions. JACC Cardiovasc Interv 2010;3:1133-8.

12. Kahlert P, Knipp SC, Schlamann M, et al. Silent and apparent cerebral ischemia after percutaneous transfemoral aortic valve implantation: a diffusion-weighted magnetic resonance imaging study. Circulation 2010;121:870-8.

13. Ghanem A, Müller A, Nähle CP, et al. Risk and fate of cerebral embolism after transfemoral aortic valve implantation: a prospective pilot study with diffusionweighted magnetic resonance imaging. J Am Coll Cardiol 2010;55:1427-32.

14. Rodés-Cabau J, Dumont E, Boone RH, et al. Cerebral embolism following transcatheter aortic valve implantation: comparison of transfemoral and transapical approaches. J Am Coll Cardiol 2011;57:18-28.

15. Erdoes G, Basciani R, Huber C, et al. Transcranial Doppler-detected cerebral embolic load during transcatheter aortic valve implantation. Eur J Cardiothorac Surg 2012;41:778-83.

16. Kahlert P, Al-Rashid F, Döttger P, et al. Cerebral embolization during transcatheter aortic valve implantation: a transcranial Doppler study. Circulation 2012;126:1245-55.

17. Van Mieghem NM, Schipper MEI, Ladich E, et al. Histopathology of embolic debris captured during transcatheter aortic valve replacement. Circulation 2013;127:2194-201.

18. Schmidt T, Akdag O, Wohlmuth P, et al. Histological findings and predictors of cerebral debris from transcatheter aortic valve replacement: the ALSTER experience. J Am Heart Assoc 2016;5.

19. Schmidt T, Schlüter M, Alessandrini H, et al. Histology of debris captured by a cerebral protection system during transcatheter valve-in-valve implantation. Heart 2016;102:1573-80.

20. Kapadia SR, Kodali S, Makkar R, et al. Protection against cerebral embolism during transcatheter aortic valve replacement. J Am Coll Cardiol 2017;69:367-77. 
21. Schmidt T, Leon MB, Mehran R, et al. Debris heterogeneity across different valve types captured by a cerebral protection system during transcatheter aortic valve replacement. JACC Cardiovasc Interv 2018;11:1262-73.

22. Naber CK, Ghanem A, Abizaid AA, et al. First-in-man use of a novel embolic protection device for patients undergoing transcatheter aortic valve implantation. EuroIntervention 2012;8:43-50.

23. Onsea K, Agostoni P, Samim M, et al. First-in-man experience with a new embolic deflection device in transcatheter aortic valve interventions. EuroIntervention 2012;8:51-6.

24. Rodés-Cabau J, Kahlert P, Neumann FJ, et al. Feasibility and exploratory efficacy evaluation of the Embrella Embolic Deflector system for the prevention of cerebral emboli in patients undergoing transcatheter aortic valve replacement: the PROTAVI-C pilot study. JACC Cardiovasc Interv 2014;7:1146-55.

25. Samim M, Agostoni P, Hendrikse J, et al. Embrella embolic deflection device for cerebral protection during transcatheter aortic valve replacement. J Thorac Cardiovasc Surg 2015;149:799-805.e1.

26. Van Mieghem NM, El Faquir N, Rahhab Z, et al. Incidence and predictors of debris embolizing to the brain during transcatheter aortic valve implantation. JACC Cardiovasc Interv 2015;8:718-24.

27. Baumbach A, Mullen M, Brickman AM, et al. Safety and performance of a novel embolic deflection device in patients undergoing transcatheter aortic valve replacement: results from the DEFLECT I study. EuroIntervention 2015;11:75-84.

28. Samim M, van der Worp B, Agostoni P, et al. TriGuard $\mathrm{HDH}$ embolic deflection device for cerebral protection during transcatheter aortic valve replacement. Catheter Cardiovasc Interv 2017;89:470-7.

29. Seeger J, Gonska B, Otto M, et al. Cerebral embolic protection during transfemoral aortic valve replacement significantly reduces death and stroke compared with unprotected procedures. JACC Cardiovasc Interv 2017;10:2297-303.

30. Wendt D, Kleinbongard P, Knipp S, et al. Intraaortic protection from embolization in patients undergoing transaortic transcatheter aortic valve implantation. Ann Thorac Surg 2015;100:686-91.

31. Lansky AJ, Schofer J, Tchetche D, et al. A prospective randomized evaluation of the TriGuard ${ }^{\mathrm{TM}} \mathrm{HDH}$ embolic DEFLECTion device during transcatheter aortic valve implantation: results from the DEFLECT III trial. Eur Heart J 2015;36:2070-8.
32. Van Mieghem NM, van Gils L, Ahmad H, et al. Filterbased cerebral embolic protection with transcatheter aortic valve implantation: the randomised MISTRAL-C trial. EuroIntervention 2016;12:499-507.

33. Haussig S, Mangner N, Dwyer MG, et al. Effect of a cerebral protection device on brain lesions following transcatheter aortic valve implantation in patients with severe aortic stenosis: the CLEAN-TAVI randomized clinical trial. JAMA 2016;316:592-601.

34. Giustino G, Mehran R, Veltkamp R, et al. Neurological outcomes with embolic protection devices in patients undergoing transcatheter aortic valve replacement: a systematic review and meta-analysis of randomized controlled trials. JACC Cardiovasc Interv 2016;9:2124-33.

35. Pagnesi M, Martino EA, Chiarito $M$, et al. Silent cerebral injury after transcatheter aortic valve implantation and the preventive role of embolic protection devices: A systematic review and meta-analysis. Int J Cardiol 2016;221:97-106.

36. Bagur R, Solo K, Alghofaili S, et al. Cerebral embolic protection devices during transcatheter aortic valve implantation: systematic review and meta-analysis. Stroke 2017;48:1306-15.

37. Giustino G, Sorrentino S, Mehran R, et al. Cerebral embolic protection during TAVR: a clinical event metaanalysis. J Am Coll Cardiol 2017;69:465-6.

38. Mohananey D, Sankaramangalam K, Kumar A, et al. Safety and efficacy of cerebral protection devices in transcatheter aortic valve replacement: a clinical endpoints meta-analysis. Cardiovasc Revasc Med 2018. [Epub ahead of print].

39. Wang N, Phan K. Cerebral protection devices in transcatheter aortic valve replacement: a clinical metaanalysis of randomized controlled trials. J Thorac Dis 2018;10:1927-35.

40. Testa L, Latib A, Casenghi M, et al. Cerebral Protection During Transcatheter Aortic Valve Implantation: An Updated Systematic Review and Meta-Analysis. J Am Heart Assoc 2018;7.

41. Eggebrecht H, Schmermund A, Mehta RH. TAVR and Stroke Prevention Importance of Cerebral Embolic Protection Device Data. J Am Coll Cardiol 2017;70:1306-7.

Cite this article as: Nombela-Franco L, Armijo G, TiradoConte G. Cerebral embolic protection devices during transcatheter aortic valve implantation: clinical versus silent embolism. J Thorac Dis 2018;10(Suppl 30):S3604-S3613. doi: $10.21037 /$ jtd.2018.09.62 